\title{
TV/Series
}

12 | 2017

Littérature et séries télévisées/Literature and TV series

\section{Literature and series}

Séries et littérature

\section{Shannon Wells-Lassagne}

\section{CpenEdition}

Journals

Electronic version

URL: http://journals.openedition.org/tvseries/2249

DOI: 10.4000/tvseries.2249

ISSN: 2266-0909

Publisher

GRIC - Groupe de recherche Identités et Cultures

\section{Electronic reference}

Shannon Wells-Lassagne, "Literature and series », TV/Series [Online], 12 | 2017, Online since 20 September 2017, connection on 10 December 2020. URL : http://journals.openedition.org/tvseries/ 2249 ; DOI : https://doi.org/10.4000/tvseries.2249

This text was automatically generated on 10 December 2020 .

\section{cc) (i) () $\Theta$}

TV/Series est mis à disposition selon les termes de la licence Creative Commons Attribution - Pas

d'Utilisation Commerciale - Pas de Modification 4.0 International. 


\title{
Literature and series
}

\author{
Séries et littérature
}

Shannon Wells-Lassagne

1 The study of "literature on screen" is not new: indeed, this terminology has long been used for the study of adaptation, perhaps most notably in Deborah Cartmell and Imelda Whelehan's Cambridge Companion to Literature on Screen ${ }^{1}$. What is less widespread, however, is the association of literature with television's "small screen" - because of its serial storytelling, television adaptation has long been relegated to limited-run miniseries (what I've called short-form adaptations), and the study of these forms has been woefully neglected (with the notable exception of Sarah Cardwell's excellent Adaptation Revisited ${ }^{2}$ ). As academic study of television and serial storytelling broadens, and as the new "Golden Age" of peak television incorporates a wealth of texts into its fictions, one could argue that small screen fictions have gone beyond either the novellike/Dickensian nature of a series like The Wire (HBO, 2002-08) or the supposedly cinematic aspirations of epics like Game of Thrones (HBO, 2011-), moving beyond adaptation as such, and into myriad forms of intertextual allusion, as varied as each of the media in question. In this issue of TV/Series, we seek to explore the many ways in which text influences the small screen - or subverts expectations of what those influences can be.

\section{"Television Culture": literature, television and sociocultural influence}

Of course, from John Fiske's landmark text Television Culture ${ }^{3}$ onwards, television studies have long focused on the sociological influences that shape the media, and the social ramifications of small screen fictions on their audiences. Our authors make apt use of cultural studies in order to investigate how adaptations of well-known source texts may reshape these sources into forms of their own. Jennifer Houdiard exposes a familiar lament in regard to television adaptations, where showrunners prefer facile characterizations (notably in terms of gender) in order to capitalize on a wider public 
than its literary forerunner. Her analysis of Spanish series Diario de una abuela de verano (la 1, 2005) and Polseres vermelles (TV3, 2011-13) finds the innovative nature of the two autobiographical essays ultimately downplayed in the fictionalization of the texts for the screen. Alexis Pichard also examines gender norms as they appear on the small screen, scrutinizing the relationship between supernatural soap Charmed (The WB, 1998-2006) and the fairy tale. He describes a complex relationship where literary associations are a way of subverting traditions and expectations on the one hand - and ultimately succumbing to them on the other, with a problematic post-feminist emphasis on "having it all". Ironically, Dennis Tredy posits that earlier versions of supernatural series ultimately offer a more radical take on destabilizing social mores. He offers a reading of early supernatural television series as both subverted adaptations of Gothic literature and groundbreaking, norm-changing shows that changed the perception of American society. Tredy's wide-ranging account of the appearance of the supernatural sitcom and the supernatural soap in the mid-sixties pinpoints how these seemingly bland series work their own subversive magic on the American public, not just of the 1960s, but on the television landscape of today.

\section{Television as a writerly medium}

Roland Barthes' distinction between "readerly" and "writerly" texts 4 seems a pertinent one for the study of television and its relationship to literature. Though Barthes of course was distinguishing between a literature whose goal was to either satisfy reader expectations or to demand that those expectations be questioned, our authors posit that television itself can be a writerly medium, both in the sense of challenging viewer expectations, and in the sense of traditionally privileging the place of the scriptwriter / producer / showrunner, an aspect of television narrative that has come to the attention of even the most dilettante of television viewers through the prominence of an "auteurist" vision of television being used to promote certain premium television offerings (David Chase's The Sopranos (1999-2007) or David Simon's The Wire, to cite examples from HBO's showrunner marketing push). In these articles, our authors seek to delineate the place of our writers, both for text and screen, and their own efforts to challenge willing viewers. Thus Isabelle Périer focuses on the first season of Penny Dreadful (Showtime, 2014-16), suggesting that this opening season proposes a sort of overview of its literary roots. She offers a structural analysis that highlights the narrative architecture making the series a prime example of television's writerly appeal - even when it happens to be borrowing from film structure.

Claire Cornillon emphasizes the transmedial nature of television in her analysis of Dr. Horrible's Sing-Along Blog (Internet, 2008). This is of course already present in the nature of the fiction, a web series: the titular vlog (video-blog) becomes the contemporary version of epistolary narrative, and the episode is no longer dependent on imposed network criteria, but rather recreates serial storytelling for its own sake. Well-known writer / showrunner / director Joss Whedon applies serial storytelling and the stage musical to the premise of the comic book, emphasizing the artifice in each of these types of fiction - only to go on to recount their collapse, making the end of the series all the more poignant. In so doing, Whedon ultimately foregrounds the importance of television as a writerly object, which draws from all sources. 
Vanessa Loubet-Poette takes advantage of her reading of Sons of Anarchy (F/X, 2008-2014) to make clear the attachment the series has to text as such, through narration, through the diary written by a recently deceased father for his son, the protagonist, which then inspires him in turn to write to his own children. The idea of writing as a means of transmission through the generations suggests a way for television, one of our newer arts, to connect to its own version of tradition, linking back to the eighteenth century novel's attempts at realism through found manuscripts of letters and journals. It may be that television relates to this older form of expression of the individual experience (rather than that of nobles around him), though of course the loose allegory of the series is of our protagonist Jax as Hamlet, dealing with the death of his father and his stepfather as head of the motorcycle gang. Loubet-Poette makes much of the importance of these texts in the narrative, but also of the paradoxical relationship between text and character: these are forbidden, incomplete texts - but which may reveal a truth otherwise unknown. They initially are the impetus of all the action, but slowly fade away to allow the narrative to predominate. If the diary writing of the series eschews predeterminism, as Vanessa Loubet-Poette posits, the same can undoubtedly be said of the TV series, which both acknowledges its textual predecessors and ultimately frees itself from them in its closing moments.

6 Florent Favard's work on Battlestar Galactica (Sci Fi, 2003-08), the most recent iteration of Dr Who (BBC1, 2005-) and Babylon 5 (PTEN, 1994-97, TNT, 1998) explores how science fiction's version of a quest narrative with an unknown but supposedly pre-determined ending relates to its reliance on both intra- et extra-diegetic texts. Flavard relates this promised ending to the Genettian idea that a novel is written from its intended conclusion, essentially an impossibility in the American television industry. This paradox between text and series, seriality and predetermined endings seems to be broached by Dr Who's use of the Pandorica myth, River Song's notebook, and Amy Pond's novel, where writing causes the future to happen, in a mise en abyme of the act of screenwriting. Likewise, the Pythia Scrolls, Battlestar Galactica's Hitchcockian macguffin which drives the quest forward, but allows sufficient leeway for innovation in a unknown both within the series and within the show's production constraints, while the sacred texts of Babylon 5 mimic the series' reliance on the show "Bible", and its fidelity to its own mythology. It is these sacred texts, Flavard suggests, that ultimately allow the series to straddle the genres of fantasy and science fiction.

7 Benoît Verdier's discussion of French series Ainsi soient-ils (Arte, 2012-15) discusses the extent to which the sacred texts of Christianity are systematically criticized and distanced from the characters, be it through cultural constraints (only men have access to the Word), critique of content, or simply ignorance of said content; in so doing, the series ultimately challenges the idea of a source text, insisting instead on television's faculty for reinterpretation (notably through serial storytelling). Though this is a series constructed around the sacred text, just like the religion it depicts, Verdier suggests that both are readings of an original text, where the homily serves not just as an interpretation of the text, but of the circumstances in the lives of the character (and in the structure of the narrative).

Charles Joseph and Delphine Letort too suggest the complexity of the relationship between television and literature through the profanation of sacred texts. The Leftovers (HBO, 2014-17) is primarily an adaptation of Tom Perrotta's novel, which itself seeks to desacralize both Scripture and its popular use in Rapture literature like the Left Behind 
series, set in a world where $2 \%$ of the population disappear without any justification, religious or otherwise. The series appears to go a step further: by associating even the first season, which hews most closely to its source text, with other literary influences, the show creators recreate the series, rewriting the source text and dramatizing its plot (both through the change of medium and through the heightening of conflict in the television version) just as it has rewritten its own sources. Using diverse texts like Yeats, the legend of Saint Hubertus, or a specific issue of National Geographic, the series posits its adaptation as both "readerly and producerly", for creators and viewers, creating new intertexts in its small screen iteration.

Ultimately, all of these interpretations of sacred texts end by questioning the possibility of an immutable, immovable text: as a postmodern art form, whose incremental nature is necessarily fluid until completed, it is perhaps inevitable that television would mistrust this sort of metanarrative.

\section{Beyond adaptation, beyond television: Allusion and transmediality in serial fiction}

The chiasmus present in the bilingual title of this special issue of TV/Series, "Literature and series/séries et littérature" is no accident; rather, it signifies a refusal to create a hierarchy between the two media evoked. Rather than see literature as a yardstick by which adaptations must be measured, or as a "high-culture" inspiration for the popular media of television, this collection seeks to show the intricate and complex relationship between the written text and the small screen, each polysemic, mutable forms that influence one another as well as their readers/viewers.

11 Thus in the final part of this special issue, our authors insist on the multiplicity of source texts in series generally considered adaptations: though the titles of shows like Sleepy Hollow (FOX, 2013-17) and Game of Thrones may initially cause motivated viewers to go back to the short story by Washington Irving or the series of novels by George R.R. Martin, Julie Richard and Justine Breton suggest that these series are not just transformative, but palimpsestic works, where Sleepy Hollow adapts not just Irving's tale, but Tim Burton's feature film adaptation, and indeed the Biblical Book of Revelations. By proposing its protagonist, Ichabod Crane as a master adapter - whose attempts to adapt to the present remind us of the distance from the ostensible source text, and inversely whose investigations or translations allow the $21^{\text {st }}$ century to make sense of relics of the past - the series expands understanding of what adaptation may be.

12 Likewise, Justine Breton suggests that the contemporary success of HBO's Game of Thrones may in fact hide a sustained allusion to what is arguably the founding myth for the fantasy genre. Arthurian legend was rewritten in The Once and Future King for a younger audience, with what Breton posits are more clearly didactic and political aims. By focusing on this intertextuality, she offers not only a possible winner to this game of thrones, highlighting bastard Jon Snow's "Wart"-like characteristics (and thus his imminent transformation into a Targaryen ruler, much as Wart becomes King Arthur), but she also offers a new perspective onto the driving narrative of the series' sprawling epic storytelling. 
Sébastien Lefait further explores Showtime's Penny Dreadful, making explicit the protean nature of television made apparent in the series' interaction between film, literature and television. His focus on the importance of transmedia storytelling suggests that the series is a fitting example of convergence culture, where the diegetic universe is stable, but the characters are (and their stories) malleable. Through the active participation of fans, what Jason Mittell refers to as "forensic fandom" ${ }^{5}$ ", the patchwork of allusion becomes a means to create one's own Frankenstein monster, piecing together disparate reified forms of literature to bring it new life $\mathrm{f}^{6}$.

Hélène Machinal's analysis of the BBC's Sherlock (2010-) also suggests that content echoes form. Machinal follows in Todorov's footsteps ${ }^{7}$, using the show to discuss the particularities of adapting detective stories, which remain textual quests, where the reader follows in the footsteps of the protagonist, deciphering text as the detective deciphers clues. However, Machinal insists on the idea that the series does not seek to recreate a false hierarchy between text and image, instead transforming Doyle's literary text into semiotic ekphrasis, insisting on the nature of our new visual culture, where Sherlock's thoughts are both words and images, an echo of the screen-bound culture of the $21^{\text {st }}$ century. In so doing, it echoes the context of Doyle's own work in the wake of the theories of Charles Darwin, an attempt to reaffirm what is human; here, the question of humanity is still present, but our limitations are cybernetic. The dizzying nature of the intertextual allusions, to source, to society, and to life imitating (and being imitated by) art contributed to Sherlock's blockbuster success.

Finally, Ronan Ludot-Vlasak posits the essential paradox inherent to this special issue of TV/Series - the association of "high culture" literature with the low culture of television fiction. Ludot-Vlasak however refuses any hierarchical relationship between the two fiction forms, seeking instead to explore the different avenues the link between the two media might take, reminding us through Agamben's work on profanation ${ }^{8}$ that making certain (literary) texts sacred may just petrify them, and through his case studies of Battlestar Galactica, Cold Case (CBS, 2003-10), or the American version of Queer as Folk (Showtime, 2000-05), he suggests that intertextual references in these television series contribute to the revival and complexification of all texts concerned. Literature is not debased, but revitalized by its association with television.

In a world where storytelling is increasingly transmedial and multiplatform, analyzing the interactions between two of the world's oldest and newest media provides the means to better understand their commonalities and specificities, but also to pinpoint the complexity of narrative fiction as a whole. The variety of texts analyzed here, and the plethora of intertextual references they use, imply that this new Golden Age is not just for television (or "post" television), but for storytelling as a whole. As our appetite for narrative grows, one could argue that the complexity of those narratives grows as well - and so I can only conclude this introduction to our special issue by wishing readers / viewers bon appétit for the Pantagruelian feast that follows.

This special issue contains one of Isabelle Périer's last published articles, as she passed away shortly before publication. We would like to dedicate this issue to her. 


\section{NOTES}

1. Deborah Cartmell, Imelda Whelehan, Cambridge Companion to Literature on Screen, Cambridge: Cambridge UP, 2007.

2. Adaptation Revisited: Television and the Classic Novel, Manchester: Manchester UP, 2002.

3. John Fiske, Television Culture (1987), London / New York: Routledge, 2011.

4. Roland Barthes, Le plaisir du texte (1973), Paris: Seuil, 2015.

5. Jason Mittell, "Forensic Fandom and the Drillable Text", http://spreadablemedia.org/essays/ mittell/. Accessed January 2015.

6. See also Julie Grossman, Literature, Film, and Their Hideous Progeny: Adaptation and ElasTEXTity, New York, NY: Palgrave Macmillan, 2017.

7. Tzvetan Todorov, “Typologie du roman policier”, Poétique de la prose, Paris : Seuil, 1971, 55-65.

8. Giorgio Agamben, Profanations, Paris, Payot \& Rivages, 2005.

\section{AUTHOR}

\section{SHANNON WELLS-LASSAGNE}

Laboratoire TIL, EA 4182

Université de Bourgogne-Franche Comté 